cyclonic depression, a destructive gale occurred in Ireland. At Valentia Observatory the pressure tube anemograph registered a gust of 96 miles an hour, which is the highest gust recorded there for at least sixteen years. Barometric readings in Iceland were unusually low during the three first days of 1933 . On January 3, pressure at sea-level was less than 928 millibars ( $27 \cdot 4$ in.) near the centre of a depression lying off the south-west coast of Iceland, but it is not possible to say by how much it fell below that value. That depression was certainly among the deepest of which we have any record since daily synoptic weather charts of the North Atlantic were first begun. On those prepared and published by the Danish and German Admiralties, there is only one depression which looks to have had such a low reading, that of February 24, 1903, which had been preceded five days earlier by another only slightly less intense.

\section{Earthquake in South-East Africa}

The strong earthquake that occurred shortly after 8.30 A.M. on December 31 in south-east Africa possesses some interest as it visited a region in which destructive shocks are almost or quite unknown. Its epicentre seems to have been in Zululand, for damage to buildings was caused at Eshowe and other places. The shock was felt all over Zululand and Natal, in various parts of the Transvaal and the Free State, and from Lorenzo Marquez on the north to the Transkei on the south. Its disturbed area must therefore have contained about a quarter of a million square miles, which is more than that shaken by the great Japanese earthquake of 1923.

\section{Ancient Man in Palestine}

IT is reported that Miss Dorothy Garrod, director of the Joint Expedition of the School of Archæology in Palestine and the American School of Prehistoric Research, has discovered further remains of Palestine man. A massive and powerful lower jaw has been found in the cave of the Oven at the foot of Mount Carmel. In an announcement of the discovery by Dr. Grant MacCurdy, of Yale University, director of the American School of Prehistoric Research, it is stated that the character of the newly discovered jaw fully conforms to the view, based upon the evidence previously discovered in the caves of Mount Carmel, that Palestine man, while presenting Neanderthaloid charasters, is of a distinct type. It is also announced that a cap or veil made of dentalia shells has been discovered in an adjacent cave. It will be remembered that in the course of the excavations of 1931, Miss Garrod found a cap of dentalia shells still attached to a skull from a mesolithic series in one of the Mugharet el-Wad caves.

\section{Cave Paintings in the Pyrenees}

Further details of an interesting discovery of the prehistoric painting of a horse in a cave in the Pyrenees, briefly announced some weeks ago, are now supplied by Science Service, Washington D.C. The cave, to be known as La Grotte de la Bastide, is situated near the village of La Bastide, Hautes
Pyrénées, and was discovered by M. Norbert Casterat, pupil of Count Bégouen. At the entrance of the cave were intact Magdalenian hearths, and on the walls were a number of engravings and polychrome paintings, including human figures, and as the central object, a polychrome painting of a horse. The horse is described as 'superb' and is an artistic production comparable with the famous horse of the Altamira cave at Santander. The figure is more than six feet long, and is executed in red with black muzzle. The mane is erect; the eye, ear and nostril being delicately engraved. High lights are indicated on shoulders, stomach and flanks. Judging from this description, the painting would appear in every way to be an exceptionally fine example of cave art.

\section{Lightning Investigation}

Mr. W. H. F. Tredre, honorary technical secretary of the Educational Section of the South African Institute of Electrical Engineers, Kelvin House, 100 Fox Street, Johannesburg, has favoured us with some interesting particulars relating to the organisation which has been established for the study of lightning in South Africa. The movement was initiated by Mr. T. P. Pask in a paper read before the South African Institute of Electrical Engineers in April 1930; as a result a committee was formed under the chairmanship of Mr. Pask. The present organisation consists of a main committee and three subsidiary committees dealing with each of the subjects research, statistics and education. With regard to the research, the chairman is Dr. B. F. J. Schonland, of Capetown-the scope of the work it is proposed to undertake includes the collection of photographs of lightning strokes and their effects taken by means of revolving lenses of the type suggested by Prof. Boys, of klydonograms and cathode ray oscillograms of lightning waves, point discharge work, etc. The activities of the statistical section may be illustrated by the fact that there are 3,500 observers throughout the Union who are collaborating by making notes on the history of storms. These observers are working under the supervision of $\mathbf{M r}$. G. W. Cox, acting chief meteorologist of the Union. The educational section will disseminate information on protective measures through the medium of the Press, schools, pamphlets, etc. During the 1933 session it has been arranged for certain of the investigators to read papers on the subjects of their work before the South African Institute of Electrical Engineers. It is anticipated that interesting results will be obtained at the end of the present lightning season.

\section{Electrification of Railways in Britain}

IN a paper by F. Lydall to the Institute of Transport read on December 12, the electrification of railways is considered under two headings, 'suburban passenger' and the 'general' electrification usually referred to as main line electrification. The main characteristics of the former type of traction are rapid acceleration and increased terminal capacity due to the elimination of locomotives and the ability 